\title{
CYTOGENETIC COMPARISON OF BIOCERAMIC, SILICONE, AND METHACRYLATE RESIN SEALERS ON T LYMPHOCYTES (MICRONUCLEI ANALYSIS)
}

\author{
DEWI ISROYATI SUGIANA, KAMIZAR NAZAR*, RATNA MEIDYAWATI, SUNNY TULIM \\ Department of Conservative, Faculty of Dentistry, Universitas Indonesia, Jakarta. Email: kamizar_kz@yahoo.com
}

Received: 27 August 2018, Revised and Accepted: 07 February 2019

\begin{abstract}
Objective: Biocompatibility refers to the manner in which materials respond to living cells and includes cytotoxicity, cytogenicity, genotoxicity, and carcinogenicity. To determine cytogenicity, we count the micronuclei that form after applying materials to living cells. Sealer is a chemical material that can be directly contacted in periapical tissue and is potentially cytogenetic. Bioceramic, silicon, and methacrylate resin sealers have ingredients that are potentially cytogenetic. We examined the interactions of these sealers with lymphocyte T-cells.
\end{abstract}

Methods: We counted the number of micronuclei following treatment with bioceramic, silicone, and methacrylate resin sealers on lymphocyte T-cells at 1,3 , and 7 days.

Results: The micronuclei scores associated with bioceramic and silicone sealers were lower than methacrylate resin ( $<<0.05$ ) between days 1,3 , and 7 . The micronuclei scores of bioceramic and silicone sealers on day 1 were higher than on days 3 and 7 . There were no significant between-group differences for bioceramic and silicone sealers on days 3 and 7 . The highest micronuclei score for methacrylate resin was on day 1.

Conclusion: Bioceramic and silicone sealers were less cytogenetic than methacrylate resin sealer. However, all of the sealers produce micronuclei on days 1,3 , and 7 .

Keywords: Cytogenetic, Bioceramic, Silicone, Methacrylate resin, Micronuclei.

(C) 2019 The Authors. Published by Innovare Academic Sciences Pvt Ltd. This is an open access article under the CC BY license (http://creativecommons. org/licenses/by/4. 0/) DOI: http://dx.doi.org/10.22159/ijap.2019.v11s1.16014

\section{INTRODUCTION}

Biocompatibility describes the response of various materials to living cells. Biocompatible materials will exhibit no irritation, inflammation, toxicity, genotoxicity, or carcinogenicity $[1,2]$ and are determined by in vitro analysis [1-3]. One biocompatibility test is cytogenicity. To determine if a material is cytogenetic, after the material is applied to living cells, we count the micronuclei [3-6]. Micronuclei are formed from lagging chromosomal fragments or whole chromosomes at anaphase which are not included in the nuclei of daughter cells [7] and appear as small spherical objects that have the same morphology and staining properties of nuclei, within the cytoplasm of daughter cells [7].

Root canal sealer is widely used in endodontic treatments $[1,5]$ and probably contacts periapical tissue. However, newer bioceramic and silicon sealers have produced different findings with regard to cytotoxicity. Some studies found that bioceramic sealer was non-toxic, while others found that it was mildly cytotoxic when freshly mixed. These discrepancies could be due to differences in setting times [4-6]. Methacrylate resin requires a setting time of $8 \mathrm{~h}$; otherwise, bioceramic and silicone sealers only require $1 \mathrm{~h}$ for setting. Loushine et al. found that the final setting time for bioceramic sealers was $160-240 \mathrm{~h}$ [18]. Candeiro et al. also showed that AH Plus ${ }^{\circledR}$ (methacrylate resin) formed $8 \%$ of micronuclei, compared to bioceramic that formed $2 \%$ of micronuclei [3].

$\mathrm{T}$ lymphocyte cells contribute to the healing process in periapical inflammation and having high rates of division characteristic. We tested the cytogenicity of bioceramic, silicone, and methacrylate resin sealers on T lymphocytes.

\section{METHODS}

Blood cultures $(0.5 \mathrm{~mL})$ from healthy donors were established in Roswell Park Memorial Institute culture medium, supplemented with 4-(2-hydroxyethyl)-1-piperazineethanesulfonic acid and L-Glutamine, $15 \%$ fetal bovineserum, penicillin-streptomycin, and phytohemagglutinin. We added $0.5 \mathrm{~mL}$ of each sealer with $5 \%$ concentration (bioceramic, silicone, and methacrylate resin) to the culture. The cultured medium was maintained in a $5 \%$ humidified $\mathrm{CO}_{2}$ incubator at $37^{\circ} \mathrm{C}$ for 1,3 , and 7 days. After incubation, we added $15 \mu$ cytochalasin B (Sigma-Aldrich) to the cultures and continued to incubate for $72 \mathrm{~h}$. The cultures were then treated with cold hypotonic solution $(0.075 \mathrm{KCl})$ to lyse the red blood cells. A fixative consisting of methanol-acetic acid (10:1) diluted with Ringer/s solution $(\mathrm{NaCl}$ and $\mathrm{KCl}$ ) was added to replace the hypotonic solution. Then, the supernatant was washed with fixative solution 2 or 3 times until the cell suspension was clear. The cells were then gently resuspended, and the suspension dropped onto clean glass slides and allowed to dry. The slides were then stained with $4 \%$ Giemsa solution in a potassium phosphate buffer $(\mathrm{pH} 7.3)$ and allowed to dry overnight. The slides were mounted with coverslips and allowed to dry completely before scoring. The slides were then analyzed by a single observer to determine the micronuclei frequency per 1000 binucleated cells.

\section{RESULTS}

From the result of experiment show that median value of micronuclei were significantly $(\mathrm{p}=0.000)$ lower for the bioceramic and silicone sealers, than for the methacrylate resin sealer (Table 1).

On days 1,3 , and 7 days, the median numbers of micronuclei were significantly $(\mathrm{p}=0.000)$ lower for the bioceramic and silicone sealers, compared to the methacrylate resin sealer (Table 2).

As shown in Fig. 1, the micronucleus lies inside a cell that has two daughter cells and is colored (purple) identically to the daughter cell. The micronucleus is approximately $1 / 6$ to $1 / 3$ the size of the daughter cell. The micronucleus image in Fig. 1 appears unchanged on days 1 , 3 , and 7 of incubation. There are no different characteristic and image 
of micronuclei in bioceramic, silicon, and methacrylate resin sealers on days 1,3 , and 7 . There is only change in the amount of micronuclei.

Table 3 presents differences in the numbers of micronuclei in the various sealer groups on incubation days 1,3 , and 7 . There were significant differences observed between days 1 and $3(\mathrm{p}=0.004)$ and days 1 and 7 $(p=0.003)$ for the bioceramic sealer. There was no significant difference between days 3 and 7 for the bioceramic group $(p=0.423)$.

There were significant differences in the numbers of micronuclei between days 1 and $3(\mathrm{p}=0.004)$, days 1 and $7(\mathrm{p}=0.004)$, and days 3 and $7(p=0.0007)$ for the methacrylate resin sealer (Table 3$)$.

\section{DISCUSSION}

We observed the cytogenicity of bioceramic, silicone, and methacrylate resin sealers on lymphocyte T-cells within micronuclei and found that

Table 1: Median (minimum-maximum) number of micronuclei after application of bioceramic, silicone, and methacrylate resin to T lymphocytes

\begin{tabular}{llll}
\hline Group & $\mathbf{n}$ & $\begin{array}{l}\text { Median score } \\
\text { (minimum-maximum) }\end{array}$ & p value \\
\hline Bioceramic & 18 & $2.00(1-5)$ & $0.000^{*}$ \\
Silicone & 18 & $2.00(1-8)$ & - \\
Methacrylate Resin & 18 & $6.50(4-15)$ & - \\
\hline
\end{tabular}

*Kruskal-Wallis $\mathrm{p}<0.05$

Table 2: Median (minimum-maximum) number of micronuclei at days 1, 3, and 7 after application of bioceramic, silicone, and methacrylate resin to $\mathrm{T}$ lymphocytes

\begin{tabular}{llllll}
\hline Group & N & Day 1 & Day 3 & Day 7 & p value \\
\hline Bioceramic & 18 & $4.00(3-5)$ & $2.00(1-3)$ & $1.50(1-2)$ & $0.000^{*}$ \\
Silicone & 18 & $6.00(4-8)$ & $2.00(1-2)$ & $1.50(1-2)$ & - \\
Methacrylate & 18 & $11.50(10-15)$ & $6.50(5-8)$ & $4.50(4-5)$ & - \\
Resin & & & & & \\
\hline
\end{tabular}

*Kruskal-Wallis $\mathrm{p}<0.05$ bioceramic and silicone sealers were associated with less cytogenesis than methacrylate resin. We selected $\mathrm{T}$ lymphocytes as our target cell due to their involvement in the healing process. The presence of micronuclei is suggestive of cell division failure or destruction during cell division into daughter cells [1].

As presented in Tables 1 and 2, we observed significant differences in the number of miconuclei among the three sealers. Bioceramic and silicone sealers appeared to be less cytogenetic than the methacrylate sealer. This result is in agreement with previous research by Zhou et al. who showed that bioceramic sealers were less cytotoxic than methacrylate resin sealers [9]. However, the test type is different between cytotoxic test which uses MTT assay and cytogenetic test which counts micronuclei. Candeiro et al. also showed from their experiment that micronuclei from contacting with methacrylate resin $\left(\mathrm{AH} \mathrm{Plus}^{\circledR}\right)$ are more than bioceramic sealers (IRoot SP® [EndoSequence, BC Sealer]) [11].

Meanwhile, Collado-González et al. found that a silicone-based

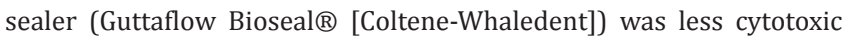
than methacrylate resin (AH Plus ${ }^{\circledR}$ ) sealer [15]. Bioceramic and silicone sealers were associated with lower micronuclei counts than methacrylate resin. This result could have been caused by calcium and silicate, which were biocompatible through the formation of hydroxyapatite crystals when calcium contacts living cells. Moreover, silicone also has a phosphoric ion that leads to the formation of apatite crystals and forms phosphate calcium as an apatite precursor. Therefore, calcium and silicate biocompatible materials, so that fewer micronuclei form following contact with silicone, compared to methacrylate resin [13].

The micronuclei value associated with methacrylate resin in Tables 1 and 2 was probably affected by epoxy material within the methacrylate resin. Candeiro et al. explained that main ingredients can accelerate the polymerization process [3]. However, it can also release formaldehyde during polymerization. Formaldehyde can lead to cellular hypoxia, destruction of cell structure, and reduced biological activity secondary to the introduction of free radicals and lactate acid. Moreover, epoxy resin also releases bisphenol A that can destroy the DNA chain and potentially destroy mitotic cells. Therefore, methacrylate resin possesses a higher cytotoxicity than bioceramic or silicone sealers [10-12].

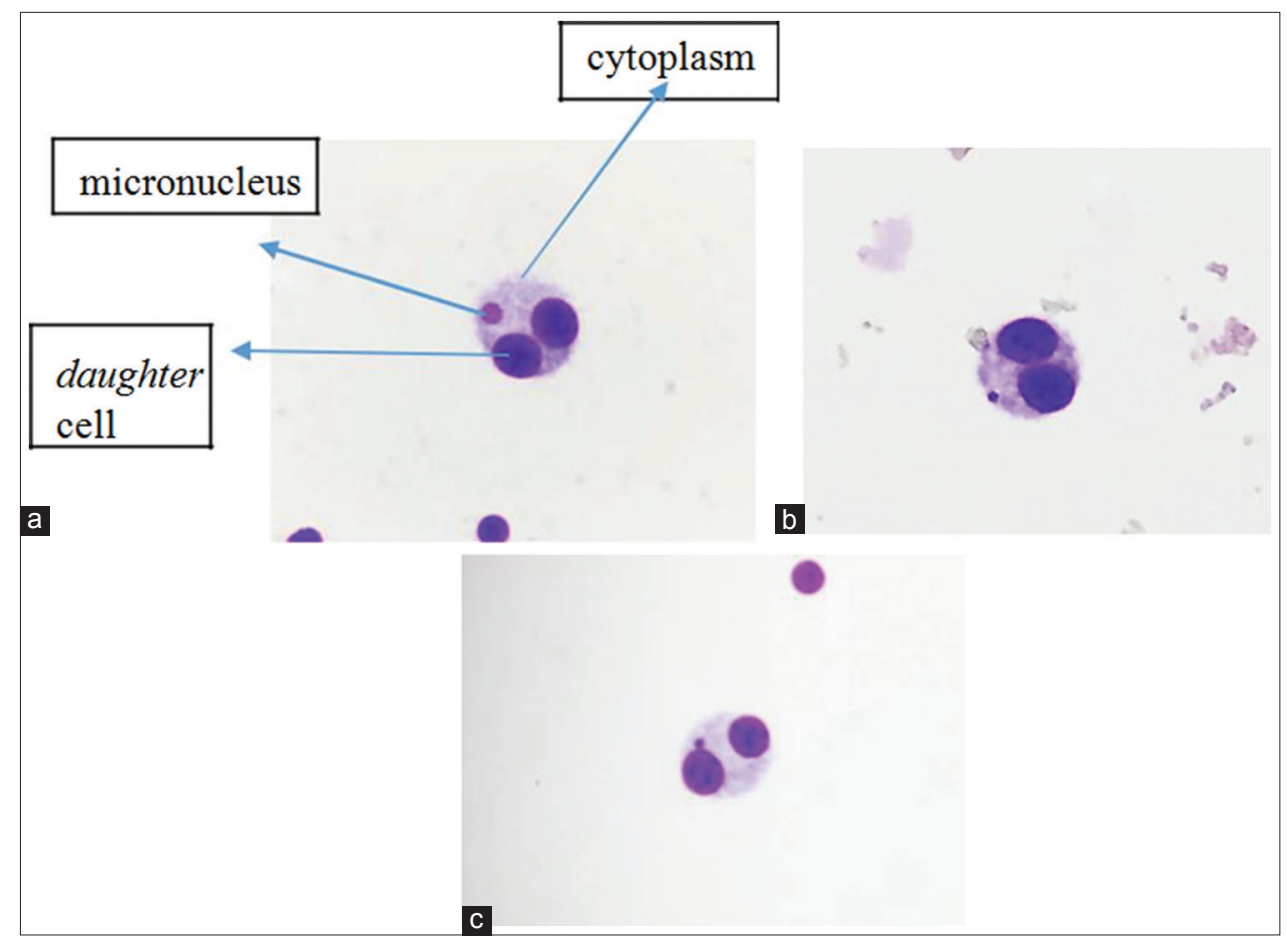

Fig. 1: Microscopic depictions of a cell micronucleus on day 1 (a), day 3 (b), and day 7 (c) of incubation 
Table 3: Changes in micronuclei counts after application of bioceramic, silicone, and methacrylate resin sealers, on T lymphocytes, on incubation days 1,3 , and 7

\begin{tabular}{|c|c|c|c|c|c|c|c|}
\hline & \multirow[t]{3}{*}{ Incubation day } & \multicolumn{6}{|c|}{ Significance value } \\
\hline & & \multicolumn{2}{|c|}{ Bioceramic } & \multicolumn{2}{|c|}{ Silicone } & \multicolumn{2}{|c|}{ Methacrylate resin } \\
\hline & & Day 1 & Day 3 & Day 1 & Day 3 & Day 1 & Day 3 \\
\hline \multirow[t]{3}{*}{ Bioceramic } & Day 1 & & & & & & \\
\hline & Day 3 & $0.004^{*}$ & & & & & \\
\hline & Day 7 & $0.003^{*}$ & 0.423 & & & & \\
\hline \multirow[t]{2}{*}{ Silicone } & Day 1 & & & & & & \\
\hline & Day 7 & & & $0.003^{*}$ & 0.241 & & \\
\hline Methacrylate & Day 1 & & & & & & \\
\hline \multirow[t]{2}{*}{ Resin } & Day 3 & & & & & $0.004^{*}$ & \\
\hline & Day 7 & & & & & $0.004 *$ & $0.007^{*}$ \\
\hline
\end{tabular}

*Mann-Whitney $\mathrm{p}<0.05$

As noted in Table 3 , we found the differences in the micronuclei score between days 1 and 3 and days 1 and 7 for bioceramic sealers. However, there were no significant differences between days 3 and 7. This means that the cytogenicity of the bioceramic sealer was higher on day 1 compared to days 3 and 7 . This result is in agreement with prior research by Vitti et al. who found decreasing cytotoxicity over the initial $24 \mathrm{~h}$. This is probably caused by the alkaline nature $(\mathrm{pH}=12)$ of the bioceramic sealer [17], potentially lethal for bacteria as well as living cells. At the conclusion of the setting time, there are a decreasing number of hydroxyl ions, thus neutralizing the $\mathrm{pH}$. Loushine et al. found that bioceramic sealers required a final setting time of $160-240 \mathrm{~h}$ and released elements that affected the viability of periodontal ligament cells $[18,19]$.

Thrikivaman et al. also explained that bioceramic sealers included zirconia nanoparticles, sized 1-7 $\mu \mathrm{m}$; meanwhile, the size of T-lymphocytes is approximately $6 \mu \mathrm{m}$ [20]. Zirconia nanoparticles enter into living cells and can produce reactive oxygen species (ROS) that increase the oxidation pressure. This mechanism is controlled by the p53 protein [20] and stimulates chromosome aberrations, destruction of chromosome fragments, and disturbs cell proliferation.

Micronuclei counts associated with contact with the silicone sealer also significantly differed between days 1 and 3 and days 1 and 7 , with no significant differences between days 3 and 7 . This means that the silicone sealer exhibited more cytogenicity on day 1 than days 3 and 7 , although micronuclei were found on all 3 days. This could have been caused by nanosilver particles contained within the sealer. According to McShan et al., nanosilver particles range from 1 to $100 \mathrm{~nm}$ in size [21]. This particle can penetrate and diffuse into cells, leading to mitochondrial dysfunction, production of ROS, and disruption of ATP synthesis. Oxidation pressures change if ROS exceeds the capacity of cellular antioxidant system, potentially destroying the cells and disturbing cell proliferation [22-24].

Table 3 also presents the differences in micronuclei associated with methacrylate resin on incubation days 1,3 , and 7 . The highest cytogenicity of methacrylate resin sealer was on day 1 , with decreasing cytogenicity on days 3 and 7 . This result is in agreement with research by Zhou et al. who found that methacrylate resin cytotoxicity decreased after setting $(8 \mathrm{~h})$ [9]. Pawińska et al. [12] also found that AH Plus ${ }^{\circledR}$ was most cytotoxic when mixed and decreased after setting time. It probably caused by the release of formaldehyde.

In this research, the three sealer materials produced discreet micronuclei values on incubation days 1,3 , and 7 . These three materials are potentially cytogenetic. We consider a material potentially cytogenetic if the amount of micronuclei formed in 1000 binuclear cells is $>40$.

All three sealer materials produced $<40$ micronuclei, with the highest value (12) associated with methacrylate resin sealer. In contrast, the silicone and bioceramic sealers had scores of 6 and 4. Therefore, the three sealers are all considered non-toxic, based the number of micronuclei; however, all have cytogenetic potential.

This research has a number of limitations. Our sample was fairly homogeneous and consisted of healthy females without systemic diseases or allergies.

\section{CONCLUSION}

This study proves that the cytogenetics of bioceramic silicone and silicon are lower than that of methacrylate resin.

\section{REFERENCES}

1. Lin LM, Rosenberg PA. Repair and regeneration in endodontics. Int Endod J 2011;44:889-906.

2. Hargreaves K, Berman L. Cohen's Pathways of the Pulp Expert Consult. $11^{\text {th }}$ ed. Maryland Heights (MO): Mosby; 2015.

3. Candeiro GT, Moura-Netto C, D'Almeida-Couto RS, AzambujaJunior N, Marques MM, Cai S, et al. Cytotoxicity, genotoxicity and antibacterial effectiveness of bioceramic endodontic siler. Int Endontic J 2016;49:858-64.

4. da Silva PT, Pappen FG, Souza EM, Dias JE, Bonetti Filho I, Carlos IZ, et al. Cytotoxicity evaluation of four endodontic sealers. Braz Dent J2008; 19:228-31.

5. Hintzsche H, Hemmann U, Poth A, Utesch D, Lott J, Stopper H, et al. Fate of micronuclei and micronucleated cells. Mutat Res 2017; 771:85-98.

6. Chang SW, Lee SY, Kang SK, Kum KY, Kim EC. In vitro biocompatibility, inflammatory response, and osteogenic potential of 4 root canal sealers: Sealapex, sankin apatite root sealer, MTA fillapex, and iRoot SP root canal sealer. J Endod 2014;40:1642-8.

7. IAEA. Cytogenetic Dosimetry: Application in Preparedness for and Responce to Radiation Emergencies. Vienna: IAEA; 2011.

8. Silva EJ, Santos CC, Zaia AA. Long-term cytotoxic effects of contemporary root canal sealers. J Appl Oral Sci 2013;21:43-7.

9. Zhou HM, Du TF, Shen Y, Wang ZJ, Zheng YF, Haapasalo M, et al. In vitro cytotoxicity of calcium silicate-containing endodontic sealers. J Endod 2015;41:56-61.

10. Pameijer $\mathrm{CH}$, Zmener O. Resin materials for root canal obturation. Dent Clin North Am 2010;54:325-44.

11. Zhou HM, Shen Y, Zheng W, Li L, Zheng YF, Haapasalo M, et al. Physical properties of 5 root canal sealers. J Endod 2013;39:1281-6.

12. Pawińska M, Łuczaj-Cepowicz E, Kierklo A, Marczuk-Kolada G, Hołownia A. Assessment of cytotoxic potential of root canal sealers after hardening-an ex vivo study. Postepy Hig Med Dosw (Online) 2015; 69:503-9.

13. Zoufan K, Jiang J, Komabayashi T, Wang YH, Safavi KE, Zhu Q, et al. Cytotoxicity evaluation of gutta flow and endo sequence BC sealers. Oral Surg Oral Med Oral Pathol Oral Radiol Endod 2011;112:657-61.

14. Al-Haddad A, Che Ab Aziz ZA. Bioceramic-based root canal sealers: A review. Int J Biomater 2016;2016:9753210.

15. Collado-González M, Tomás-Catalá CJ, Oñate-Sánchez RE, Moraleda JM, Rodríguez-Lozano FJ. Cytotoxicity of guttaFlow bioseal, 
guttaFlow2, MTA fillapex, and AH plus on human periodontal ligament stem cells. J Endod 2017;43:816-22.

16. Saygili G, Saygili S, Tuglu I, Davut Capar I. In vitro cytotoxicity of guttaFlow bioseal, guttaFlow 2, AH-plus and MTA fillapex. Iran Endod J 2017; 12:354-9.

17. Vitti RP, Prati C, Sinhoreti MA, Zanchi CH, Souza E Silva MG, Ogliari FA, et al. Chemical-physical properties of experimental root canal sealers based on butyl ethylene glycol disalicylate and MTA. Dent Mater 2013;29:1287-94

18. Loushine BA, Bryan TE, Looney SW, Gillen BM, Loushine RJ, Weller RN, et al. Setting properties and cytotoxicity evaluation of a premixed bioceramic root canal sealer. J Endod 2011:37:673-7.

19. Victoria-Escandell A, Ibañez-Cabellos JS, de Cutanda SB, BerenguerPascual E, Beltrán-García J, García-López E, et al. Cellular responses in human dental pulp stem cells treated with three endodontic materials.
Stem Cells Int 2017;2017:8920356.

20. Thrikivaman G, Madras G, Basu B. In vitro assessment and mechanisms of toxicity of bioceramic materials and its wear particulates. RSC Adv 2014;4:12763-81.

21. Corrêa JM, Mori M, Sanches HL, da Cruz AD, Poiate E Jr., Poiate IA, et al. Silver nanoparticles in dental biomaterials. Int $\mathbf{J}$ Biomater 2015;2015:485275.

22. McShan D, Ray PC, Yu H. Molecular toxicity mechanism of nanosilver. J Food Drug Anal 2014;22:116-27.

23. Feng X, Chen A, Zhang Y, Wang J, Shao L, Wei L, et al. Application of dental nanomaterials: Potential toxicity to the central nervous system. Int J Nanomedicine 2015;10:3547-65.

24. Zhang XF, Liu ZG, Shen W, Gurunathan S. Silver nanoparticles: Synthesis, characterization, properties, applications, and therapeutic approaches. Int J Mol Sci 2016;17:1534 